ARCHIWA - KanCELARIE - ZBIORY

NR 1 (3)/2010

Dariusz Magier

\title{
Archiwum Komitetu Wojewódzkiego PZPR w BiaŁej Podlaskiej
}

W myśl ustawy archiwalnej $^{1}$ dokumentacja wytworzona przez Polską Zjednoczoną Partię Robotniczą została włączona w skład narodowego zasobu archiwalnego, jednakże archiwa partii nigdy nie podlegały nadzorowi państwowej służby archiwalnej. Do końca lat pięćdziesiątych miały one charakter składnic akt. W 1955 roku składnice zostały przejęte przez wydziały propagandy komitetów wojewódzkich i wkrótce nastąpiło przekształcenie ich w archiwa komitetów wojewódzkich ${ }^{2}$. Zadanie zabezpieczania dokumentacji wytworzonej przez struktury partii komunistycznej w Polsce nadzorowały kolejno: Wydział Historii Partii przy KC PPR (później PZPR), Archiwum KC PZPR, od 1971 roku zaś Centralne Archiwum KC PZPR (dalej cyt. CA

Dariusz Magier - Archiwum Państwowe w Lublinie, Oddział w Radzyniu Podlaskim i Instytut Historii Uniwersytetu Przyrodniczo-Humanistycznego w Siedlcach, e-mail: dmagier@archiwozofia.com. Zainteresowania badawcze: idea archiwalna, biurokracja XX w., polski ruch komunistyczny.

${ }^{1}$ Ustawa $z$ dnia 14 lipca 1983 r. o narodowym zasobie archiwalnym $i$ archiwach, DzU, 1983, nr 38, poz. 173 (tekst pierwotny).

${ }^{2}$ Archiwa Komitetów Wojewódzkich PZPR. Zbiór przepisów, Warszawa 1969, s. 2-3; I. Chmielewska, K. Hołownia, Problemy porzadkowania akt partyjnych z bytego Archiwum Komitetu Wojewódzkiego Polskiej Zjednoczonej Partii Robotniczej w Olsztynie z lat 1948-1990 (z wytaczeniem zespotu Komitetu Wojewódzkiego PZPR) [on-line]. [Dostęp 10 lutego 2010 r.]. Dostępny w World Wide Web: http://www.archiwa.gov.pl/images/ stories/file/pdf/chmielewska_holownia.pdf, s. 1. 
KC PZPR). Wraz z archiwami komitetów wojewódzkich tworzyło ono sieć archiwów PZPR, z własnymi przepisami, kadrą oraz metodyką archiwalną ${ }^{3}$.

W związku z wprowadzeniem w 1975 roku nowego podziału administracyjnego kraju przed CA KC PZPR stanęło zadanie koordynacji zabezpieczenia akt partyjnych likwidowanych komitetów powiatowych oraz organizacji archiwów nowych komitetów wojewódzkich. Przypominano o potrzebie zabezpieczania wytworzonej dokumentacji, a w maju 1976 roku wyartykułowano dosyć szczegółowe przepisy postępowania $\mathrm{z}$ aktami w archiwach komitetów wojewódzkich. Nowe komitety wojewódzkie partii komunistycznej zostały zobowiązane do utworzenia własnego archiwum, wygospodarowania na nie pomieszczeń i obsadzenia kadrą .

Archiwum Komitetu Wojewódzkiego PZPR w Białej Podlaskiej (dalej cyt. AKW) - zgodnie z wytycznymi CA KC PZPR - stanowiło archiwum całej organizacji partyjnej na terenie województwa bialskopodlaskiego ${ }^{5}$. Zostało powołane do istnienia w 1976 roku, a w strukturze organizacyjnej i etatowej było usytuowane w Wydziale Pracy Ideowo-Wychowawczej (kolejne nazwy wydziału to: w latach 1981-1987 Wydział Ideologiczny; w latach 1987-1990 Wydział Ideologiczny i Propagandy). Nadzór merytoryczny nad AKW sprawowało CA KC PZPR, natomiast polityczny - sekretarz ds. ideologicznych bialskopodlaskiego komitetu wojewódzkiego ${ }^{6}$. Zadaniem nowo powołanego archiwum było przejmowanie materiałów archiwalnych wytworzonych przez KW, komitety miejskie, miejsko-gminne i zakładowe oraz wytypowane podstawowe organizacje partyjne. Dla każdego z nich były tworzone oddzielne zespoły archiwalne. $\mathrm{Z}$ komitetu wojewódzkiego do jego archiwum miały być przekazywane akta powstałe w wyniku działalności władz: protokoły konferencji Wojewódzkiej Komisji Rewizyjnej, Wojewódzkiej Komisji

3 J. Durko, Archiwa Polskiej Zjednoczonej Partii Robotniczej, Archiwa Polskiej Zjednoczonej Partii Robotniczej, nr 1, 1980, s. 3-9; zob. E. Łaborewicz, Dzieje akt $i$ archiwum Komitetu Wojewódzkiego PZPR w Legnicy [on-line]. [Dostęp 10 lutego 2010 r.]. Dostępny w World Wide Web: http://www.archiwa.gov.pl/images/stories/file/pdf/edyta_laborewicz.pdf, s. 4.

${ }^{4}$ Wytyczne w sprawie dziatalności archiwów KW PZPR, Warszawa 1976; zob. również: W. Horst, Kancelarie i archiwa Centralnego Komitetu Wykonawczego Polskiej Partii Socjalistycznej, Komitetu Centralnego Polskiej Partii Robotniczej i Komitetu Centralnego Polskiej Zjednoczonej Partii Robotniczej (1944-1990), Warszawa 2006, s. 208; E. Łaborewicz, dz. cyt., s. 4.

5 Wytyczne w sprawie dziatalności archiwów KW PZPR.

${ }^{6}$ Archiwum Państwowe w Lublinie, Oddział w Radzyniu Podlaskim (dalej: APL, O/R), Komitet Wojewódzki Polskiej Zjednoczonej Partii Robotniczej w Białej Podlaskiej [1946-1974] 1975-1990 (dalej: KW PZPR w BP), sygn. 612, s. 80. 
Kontroli Partyjnej, posiedzeń plenarnych i Egzekutywy oraz dokumentacja poszczególnych wydziałów. Materiały archiwalne po 2-3 latach od wytworzenia miały przekazywać do AKW również wszystkie instancje I stopnia (3 komitety miejskie, 3 komitety miejsko-gminne oraz 32 komitety gminne), a także 96 „reprezentatywnych” podstawowych organizacji partyjnych. W tej grupie przekazaniu podlegały protokoły konferencji sprawozdawczo-wyborczych, posiedzeń plenarnych, posiedzeń komisji rewizyjnych i kontroli partyjnej, posiedzeń ogólnych i ankiety statystyczne?

Przez cały okres funkcjonowania obsada personalna AKW nie była liczniejsza niż jeden etat. $Z$ reguły zajmował go pracownik polityczny na stanowisku starszego inspektora/instruktora. W latach 1976-1979 piastował je Zenon Borysewicz, natomiast od roku 1983 do końca działalności archiwum - Tomasz Demidowicz. Od stycznia 1980 do września 1983 roku działalność AKW zamarła w ogóle z powodu braku obsady kadrowej. Obaj kierownicy AKW byli młodymi pracownikami aparatu komunistycznego, którzy w momencie rozpoczęcia pracy archiwisty mieli niewiele ponad 30 lat i legitymowali się wykształceniem wyższym. Demidowicz miał nawet tytuł doktora nauk humanistycznych ${ }^{8}$. Zasady i kierunek pracy AKW przez cały okres jego funkcjonowania wyznaczały: 1) instrukcje dotyczące gromadzenia, przechowywania i przekazywania akt KW i instancji niższych z 1976 r. ${ }^{9}$, 2) instrukcja Sekretariatu KC PZPR w sprawie dokumentacji partyjnej w komitetach i organizacjach PZPR z grudnia 1982 r. ${ }^{10}, 3$ ) uchwała Biura Politycznego KC PZPR w sprawach archiwów partii z sierpnia $1984 \mathrm{r}^{11}{ }^{11}$ 4) wytyczne CA KC PZPR w sprawie działalności archiwów KW z 1986 r. $^{12}$, 5) wytyczne w sprawie przygotowania, zabezpieczenia i przekazania akt PZPR do Archiwum KW PZPR w Białej Podlaskiej z kwietnia 1988 r. ${ }^{13}$, 6) bieżące instrukcje i zalecenia KC PZPR.

$\mathrm{Na}$ początku działalności AKW jego kierownik został przeszkolony przez pracowników archiwum komitetu centralnego partii i jesienią 1976 roku złożył do Wydziału Organizacyjnego KW „zapotrzebowanie na sprzęt i mate-

7 Wytyczne w sprawie dziatalności archiwów KW PZPR; E. Łaborewicz, dz. cyt., s. 4-5; APL, O/R, KW PZPR w BP, sygn. 610, s. 12 - „Informacja o działalności Archiwum Komitetu Wojewódzkiego PZPR w Białej Podlaskiej w 1977 roku”.

8 APL, O/R, KW PZPR w BP, sygn. 610, s. 1-2; tamże, sygn. 611, s. 1 i 60.

9 Tamże, sygn. 609, s. 19-42.

10 W. Horst, dz. cyt., s. 303-315.

${ }^{11}$ APL, O/R, KW PZPR w BP, sygn. 609, s. 151-154.

12 Tamże, s. 200-278.

13 Tamże, s. 159-199. 
riały niezbędne do prawidłowego funkcjonowania Archiwum"14. Na jego potrzeby przeznaczono dwa jednakowe pomieszczenia o wymiarach $3,8 \mathrm{~m} \times$ $\times 2,8 \mathrm{~m}$ każde, ulokowane $\mathrm{w}$ piwnicy nowo wybudowanej stołówki komitetu. Temperatura $\mathrm{w}$ pomieszczeniach była zmienna, ciepło $\mathrm{w}$ okresie zimowym było utrzymywane za pomocą centralnego ogrzewania. Zainstalowano oświetlenie jarzeniowe. W 1976 roku archiwista zdołał jeszcze opracować „Instrukcję dotyczącą gromadzenia, przechowywania i przekazywania akt KM, KM-G, KG, KZ i reprezentatywnych POP do Archiwum KW PZPR [w Białej Podlaskiej]” oraz osobną „Instrukcję dotyczącą gromadzenia, przechowywania i przekazywania akt KW [PZPR w Białej Podlaskiej] do Archiwum KW PZPR"15, które Sekretariat KW zatwierdził 20 grudnia 1976 roku.

Do końca 1976 roku uporządkowano plakaty i zdjęcia będące w posiadaniu macierzystego Wydziału Pracy Ideowo-Wychowawczej, zakupiono propagandowe zestawy szkoleniowe obrazujące historię polskiego ruchu rewolucyjnego oraz zorganizowano pierwsze wystawy ${ }^{16}$. Sformułowano też stałe zadania AKW, do których należało: przejmowanie, opracowywanie i przechowywanie akt PZPR z terenu województwa bialskopodlaskiego, gromadzenie i opracowywanie wspomnień, zdjęć i pamiątek działaczy ruchu rewolucyjnego, organizowanie wystaw tematycznych związanych z rocznicami i uroczystościami partyjno-państwowymi, przeprowadzanie kontroli i szkoleń kancelaryjno-archiwalnych w instancjach stopnia podstawowego ${ }^{17}$.

W 1977 roku lokal magazynowy AKW wyposażono w regały metalowe, pomieszczenie biurowe zaś w biurko, krzesła, maszynę do pisania oraz magnetofon kasetowy do nagrywania wspomnień „kombatantów” ruchu komunistycznego. Przejęto pierwsze akta wytworzone w 1975 roku. Do końca tego roku w magazynie archiwum znalazły się 324 j.a., które zajęły na regałach 2,30 m.b. Tworzyły one 135 zespołów archiwalnych ${ }^{18}$. W ciągu 10 następnych lat funkcjonowania AKW metraż jego zasobu powiększył się niemal 30-krotnie (por. rys. 1). Według stanu na dzień 31 grudnia 1988 roku wynosił on ogółem 66,10 m.b., z czego 70\% oceniano jako opracowany. W stanie nieopracowanym pozostawały materiały archiwalne z lat 1982-1986 (akta z lat 1987-1988 nadal pozostawały w wydziałach KW i instancjach nizszych), wytworzone przez Wydział Organizacyjno-Polityczny, Wojewódzki

14 Tamże, sygn. 610, s. 4 - „Informacja o działalności Archiwum Komitetu Wojewódzkiego PZPR w Białej Podlaskiej [w 1976 r.]" z 11 I 1977 r.

15 Tamże, sygn. 609, s. 19-29, 30-42.

16 Tamże, sygn. 610, s. 4-5.

17 Tamże, s. 6-7 - plan pracy AKW na 1977 r.

18 Tamże, s. 4 - sprawozdanie z działalności AKW w 1977 r. 
Ośrodek Kształcenia Ideologicznego, Wydział Ideologiczny i Propagandy, komitety gminne oraz reprezentatywne POP. Ponadto w AKW przechowywano zdjęcia i plakaty ${ }^{19}$.

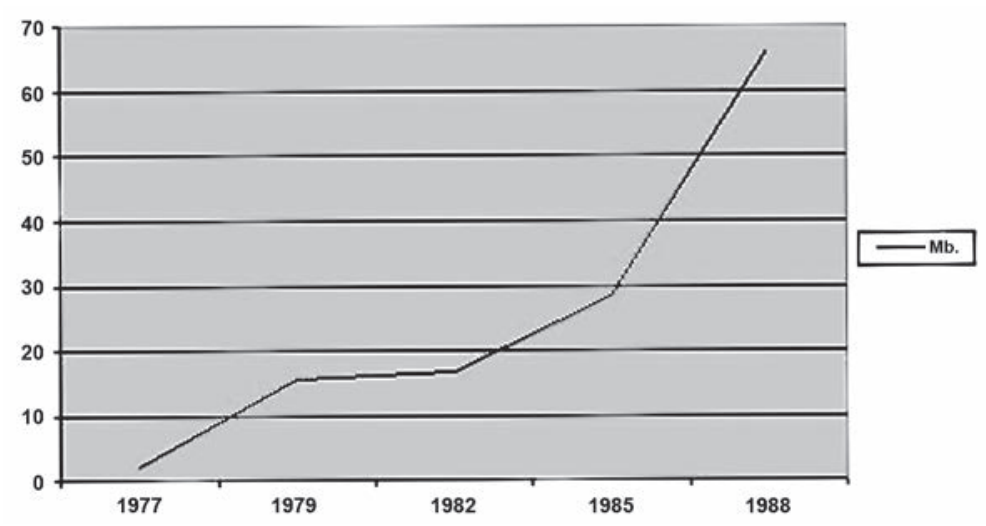

Rys. 1. Przyrost zasobu w Archiwum KW PZPR w Białej Podlaskiej w latach 1977$-1988$

Źródło: APL, O/R, KW PZPR w BP, sygn. 610, s. 12-17; sygn. 611, s. 1-3; sygn. 613, s. 1-7, 18-23; obliczenia własne.

Akta przejmowane do AKW były ewidencjonowane w księdze inwentarzowej zawierającej następujące informacje: 1) lp., 2) data przyjęcia, 3) nazwa zespołu, 4) daty krańcowe, 5) liczba j.a. i m.b., 6) nr spisu zdawczo-odbiorczego, 7) uwagi. Początkowo spisom zdawczo-odbiorczym nadawano numery w obrębie roku, natomiast od 1984 roku (po zmianie na stanowisku archiwisty komitetu) otrzymywały one numerację ciągłą ${ }^{20}$. Spisy zdawczo-odbiorcze akt przekazywanych do Archiwum KW PZPR były sporządzane na formularzach, w których odnotowywano: 1) lp., 2) tytuł akt, 3) rok, 4) liczbę pozycji, 5) kategorię archiwalną, 5) uwagi (rys. 2). W lewym górnym rogu umieszczano nazwę wydziału/instancji będącej twórcą dokumentacji. W prawym górnym rogu przewidziano miejsce na numer spisu oraz datę przyjęcia akt. Spisów zdawczo-odbiorczych zachowało się niewiele. Po krótkim okresie ich prawidłowego wypełniania na początku funkcjonowania KW, w latach osiem-

19 Tamże, sygn. 613, s. 18-23 - ankieta sprawozdawcza AKW wg stanu na 31 XII 1988 r. Ostatnie dane ewidencyjne AKW pochodzą z lipca 1989 r. Według nich w okresie 1 I-14 VII 1989 r. przejęto ponad 7,50 m.b. akt, tamże, sygn. 614 - księga inwentarzowa AKW.

20 Tamże, sygn. 614 - księga inwentarzowa AKW. 


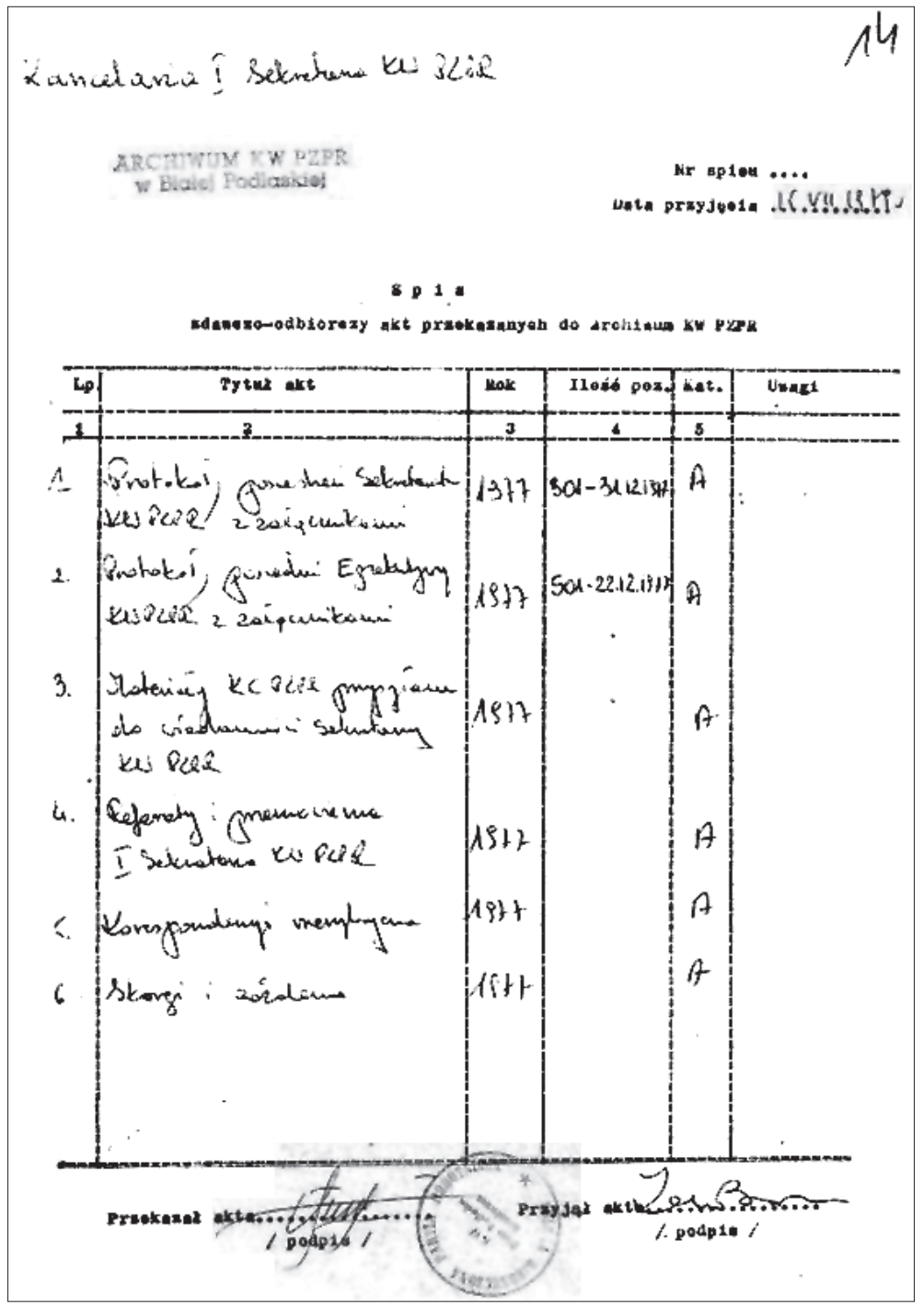

Rys. 2. Przykładowy spis zdawczo-odbiorczy dokumentacji przekazywanej do Archiwum KW PZPR w Białej Podlaskiej

Źródło: APL, O/R, KW PZPR w BP, sygn. 615, s. 14.

dziesiątych obserwujemy wyraźne pogorszenie się tego stanu. Formularze są wypełnione niekompletnie, brakuje podpisów, nazw twórców, numeracji. Na jednym spisie ewidencjonowano zarówno materiały archiwalne, jak i dokumentację niearchiwalną. W połączeniu z informacjami archiwisty KW na te- 
mat współpracy na linii: AKW-komórki organizacyjne KW/instancje pozwala to sądzić, że dokumentacja była przekazywana do magazynu archiwalnego z reguły w stanie nieuporządkowanym i bez spisów zdawczo-odbiorczych ${ }^{21}$.

W miarę napływania akt do AKW materiały archiwalne były sukcesywnie opracowywane. Na proces ten składało się porządkowanie teczek, naniesienie foliacji, pakowanie w zamawiane obwoluty tekturowe, na które naklejano specjalne etykiety. Zawierały one: nazwę archiwum, nazwę zespołu (gdy twórcą akt był KW, uzupełniano go nazwą komórki organizacyjnej, która akta wytworzyła), opis jednostki, czyli tytuł teczki, daty skrajne jednostki (stosowano daty dzienne lub miesięczne wytworzenia akt), liczbę kart oraz sygnaturę archiwalną (rys. 3).

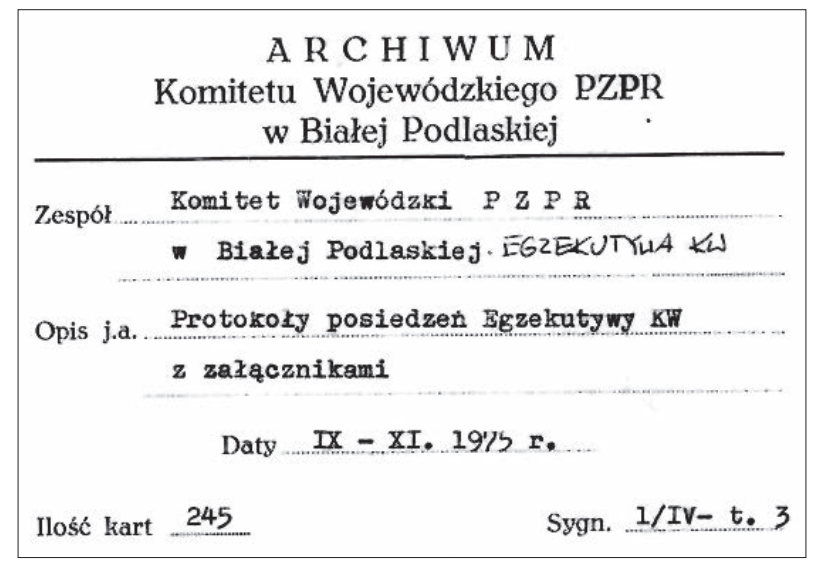

Rys. 3. Przykładowy sposób wypełnienia etykiety na teczki archiwalne Archiwum KW PZPR w Białej Podlaskiej

Źródło: APL, O/R, KW PZPR w BP, sygn. 64.

Sygnatura AKW miała budowę trój- lub czteroczłonową, na którą składały się: arabski numer zespołu łamany przez rzymski numer grupy akt (komórki organizacyjnej, serii) i kolejny numer inwentarzowy. W przypadku, gdy jednorodna zawartość jednostki archiwalnej nie mieściła się w jednej teczce,

21 Tamże, sygn. 610, s. 67 - informacja o pracy AKW na dzień 20 V 1986 r. Kierownik AKW odnotowywał w niej, że „nie wykonywana jest instrukcja [zakładająca], że archiwum przyjmuje z kancelarii dokumenty tylko w stanie uporządkowanym; nie są wykonywane przez pracowników kancelarii (sekretariaty) obowiązki, np. przechowywania akt, sporządzania spisów akt i przekazywania ich do archiwum”. 
dzielono ją na tomy i dodawano numer tomu jako czwarty element sygnatury. Podstawowym środkiem ewidencyjnym materiałów archiwalnych opracowanych w AKW były inwentarze kartkowe, zbudowane według znormalizowanego wzoru państwowej sieci archiwalnej NDAP-0-3, opracowanego przez Adama Wolffa. Ich strukturę oraz sposób wypełniania ujednolicały wytyczne AKW w Białej Podlaskiej z kwietnia 1988 roku $^{22}$. Zwraca uwagę odmienny od wytycznych Naczelnej Dyrekcji Archiwów Państwowych sposób wypełniania rubryk 6 i 7 inwentarza ${ }^{23}$. W rubryce 6 wpisywano jedynie formę sporządzenia dokumentów (np. maszynopis, rękopis), w 7 - liczbę kart w jednostce archiwalnej (rys. 4).

Niszczenie dokumentacji niearchiwalnej w AKW oraz kat. Bc w komórkach organizacyjnych komitetu wymagało specjalnej procedury brakowania. $\mathrm{Z}$ kolei niszczenie dokumentacji w instancjach I stopnia wymagało zgody AKW. Przepisy przewidywały, że dla brakowanej dokumentacji powinien zostać sporządzony protokół zniszczenia akt, w którym należało odnotować rodzaj akt, lata, ilość dokumentacji. Protokół swoimi podpisami mieli uwierzytelniać: sekretarz komitetu (kierownik wydziału), przewodniczący komisji rewizyjnej oraz archiwista $\mathrm{AKW}^{24}$. Niestety, wśród materiałów archiwalnych KW PZPR w Białej Podlaskiej nie zachował się jakikolwiek ślad ewidencji brakowania zasobu. Z dokumentacji sprawozdawczej wiadomo jednak, że począwszy od 1984 roku, przeprowadzano brakowanie dokumentacji niearchiwalnej. W 1984 roku wykazywano oficjalne zniszczenie niespełna 1 m.b. dokumentacji, w latach 1985-1986 - ponad 2 m.b., w latach 1987-1988 zaś - 3,60 m.b. ${ }^{25}$ Występowanie wśród przejętej dokumentacji wielu luk w materiale aktowym, których wielkość można ocenić na około 30\% dla akt samego KW (m.in. dokumentacja kancelarii tajnej, protokoły z posiedzeń Egzekutywy i Sekretariatu KW z lat 1985-1990, dokumentacja budżetowa z lat 1988-

22 Tamże, sygn. 609, s. 187 - „Wytyczne w sprawie przygotowania, zabezpieczenia i przekazywania akt [KW] KM, KM-G, KG, KZ, reprezentatywnych POP do Archiwum KW PZPR w Białej Podlaskiej”.

23 Zarzadzenie nr 17 a NDAP z 28 VII 1960 r. w sprawie ewidencji materiatów archiwalnych przechowywanych poza archiwami państwowymi, [w:] Zbiór przepisów archiwalnych wydanych przez Naczelnego Dyrektora Archiwów Państwowych w latach 1952-2000, wyb. i oprac. M. Tarakanowska, E. Rosowska, Warszawa 2001, s. 277-279; Pismo okólne nr 2 NDAP z 28 V 1984 r. w sprawie wprowadzenia wskazówek metodycznych do sporządzania inwentarza archiwalnego zespotów (zbiorów) akt wytworzonych w okresie kancelarii akt spraw (XIX-XX w.), [w:] tamże, s. 502-514.

24 APL, O/R, KW PZPR w BP, sygn. 609, s. 177-178 - „Wytyczne w sprawie przygotowania, zabezpieczenia i przekazania akt [KW] KM, KM-G, KG, KZ”.

25 Tamże, sygn. 613, s. 3-23 - ankiety sprawozdawcze AKW za lata 1984-1988. 


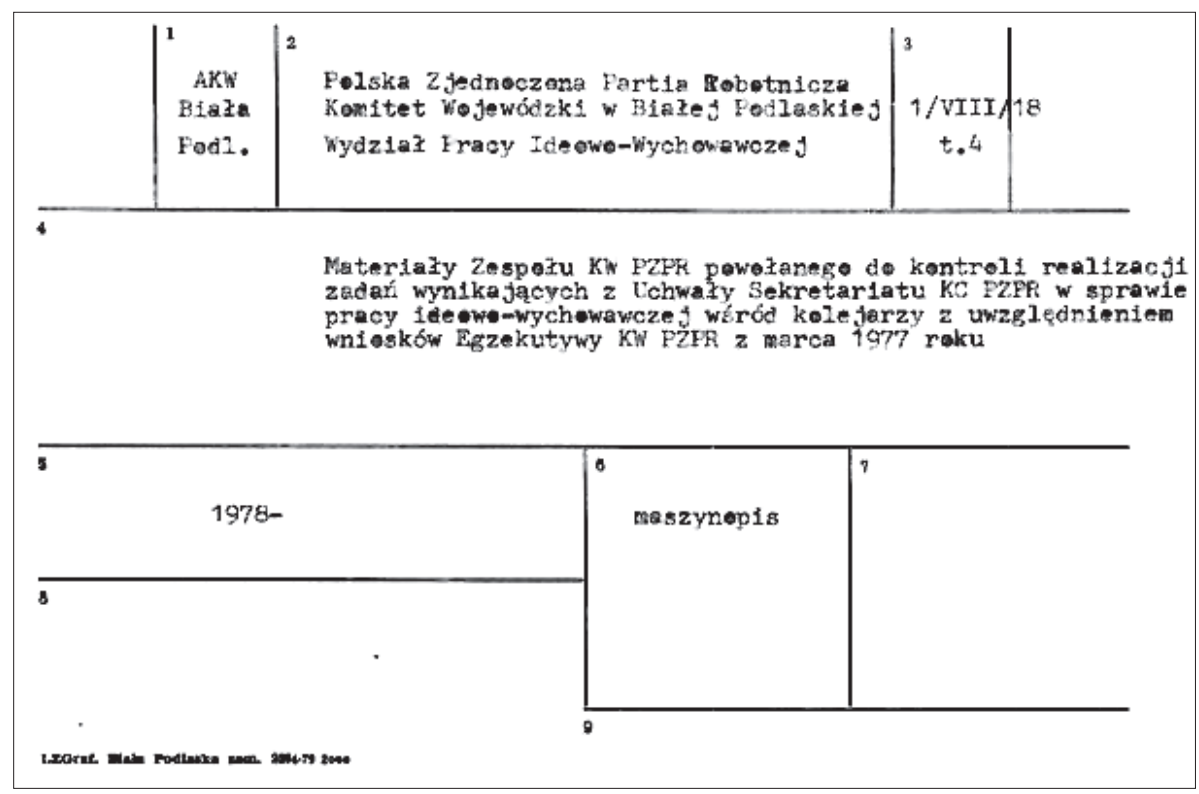

Rys. 4. Przykładowa karta inwentarzowa sporządzona w Archiwum KW PZPR w Białej Podlaskiej

Źródło: APL, O/R, archiwum zakładowe, teczka zespołu: Komitet Wojewódzki PZPR w Białej Podlaskiej, dawne środki ewidencyjne.

-1990 ${ }^{26}$, może wskazywać na wzmożone, „dzikie”, brakowanie dokumentacji w końcowym okresie istnienia PZPR oraz w czasie bezpośrednio poprzedzającym przekazanie akt do archiwum państwowego. Podobnie działo się to na terenie całego kraju ${ }^{27}$.

Cały okres istnienia Archiwum Komitetu Wojewódzkiego partii komunistycznej w Białej Podlaskiej był naznaczony występowaniem bardzo trudnych warunków lokalowych. Pomieszczenia przeznaczone na archiwum były zbyt małe, by prawidłowo spełniać funkcje magazynu, pomieszczenia biurowego do pracy oraz pracowni dla korzystających. Kontrola AKW w Białej Podlaskiej przeprowadzona w lutym 1984 roku przez Centralną Komisję Rewizyjną PZPR potwierdziła, że lokal „nie zapewnia warunków niezbędnych

26 D. Magier, Wstęp do inwentarza zespołu akt: Komitet Wojewódzki Polskiej Zjednoczonej Partii Robotniczej w Białej Podlaskiej, Radzyń Podlaski 2006, s. VI [mps w APL, O/R].

27 Zob. np. E. Łaborewicz, dz. cyt., s. 7-8. 
do przechowywania zasobu archiwalnego PZPR ani sprawnego funkcjonowania archiwum"28. Wskazywano przy tym w szczególności na:

- zbyt małe pomieszczenia, które uniemożliwiają sprawne funkcjonowanie archiwum;

- brak możliwości utrzymania stałej temperatury i wilgotności powietrza (w okresie letnim następowało zbytnie przesuszanie akt, w zimie - zawilgocenie);

- duże zagęszczenie powierzchni użytkowej powodujące niszczenie akt i niemożność utrzymania czystości;

- szkodliwe dla personelu warunki pracy ze względu na całodobowe oświetlenie sztuczne, brak wentylacji, silny zapach papieru, kurz i sąsiedztwo powielarni;

- brak pełnego zabezpieczenia przeciwpożarowego ${ }^{29}$.

W informacji o realizacji wniosków pokontrolnych kierownik AKW pisał w grudniu 1984 roku, że pomimo interwencji podejmowanych w Wydziale Ogólnym, Sekretariacie KW oraz Wojewódzkiej Komisji Rewizyjnej, powyższe nieprawidłowości nie zostały usunięte. Nadmieniał jednak, że „Archiwum KW liczy na podjęcie stosownych działań przez Komitet Wojewódzki, mających na celu poprawę warunków lokalowych"30.

Dwa lata później informował: „Nie doczekała się dotychczas realizacja i koncepcja zmiany lokalizacji AKW, jak też poprawy warunków przechowywania materiałów. Zalecane doposażenie w sprzęt ppoż. ograniczono do wymiany gaśnic i wyposażenia w koce azbestowe, nie ma na wyposażeniu termohydrografu, nie została poprawiona instalacja elektryczna"31.

Kompleksowa kontrola KW PZPR w Białej Podlaskiej przeprowadzona przez Centralną Komisję Kontroli Partyjnej w listopadzie 1988 roku potwierdziła wszystkie wcześniejsze spostrzeżenia odnośnie do fatalnych warunków lokalowych AKW. Zmusiło to władze wojewódzkiej instancji partii do oświadczenia, że „W wyniku dobudowania nowego skrzydła budynku KW przewidziano dla AKW lokal, również niestety piwniczny, ale z możliwością wentylacji naturalnej (okiennej) i powiększoną powierzchnią maga-

28 APL, O/R, KW PZPR w BP, sygn. 612, s. 9-17 - protokół z kontroli AKW 10 II 1984 r.

29 Tamże.

30 Tamże, s. 45-46 - informacja AKW o realizacji wniosków pokontrolnych z 24 XII 1984 r.

31 Tamże, sygn. 610, s. 86 - informacja o pracy AKW z grudnia 1986 r. 
zynową" ${ }^{32}$. Nic nie wskazuje, by obietnice te zdołano wcielić w życie przed rozwiązaniem PZPR.

Taka sytuacja wywierała niewątpliwy wpływ na dyskomfort kierownika archiwum, który nie tylko nie miał należytych warunków do pracy, niezbędnych do przestrzegania przepisów kancelaryjno-archiwalnych, ale także nie znajdował wsparcia u swoich zwierzchników. Takie też wrażenie niesie lektura ankiety wypełnionej przez archiwistę KW PZPR w Białej Podlaskiej w styczniu 1988 roku. Tomasz Demidowicz, po 5 latach pracy (podjętej „po dłuższej namowie, pełnej gołosłownych obiecanek"), na pytanie o potrzebę podnoszenia kwalifikacji zawodowych odpowiadał szczerze, że nie widzi takiej potrzeby. „Podnoszenie kwalifikacji - pisał - nie ma bowiem żadnego wpływu na jakikolwiek awans, wręcz przeciwnie, za wysokie kwalifikacje można ponosić karę w sensie płacy i narzucania dodatkowych zadań”33. Była to niewątpliwie wypowiedź oparta na osobistym doświadczeniu. Pamiętajmy bowiem, że Demidowicz mógł pochwalić się tytułem doktora nauk humanistycznych oraz ukończeniem Podyplomowego Studium Bibliotekoznawstwa i Informacji Naukowej na Uniwersytecie Wrocławskim ${ }^{34}$. Wskazywał przyczyny hamujące realizację instrukcji kancelaryjno-archiwalnych, wśród których wymieniał brak synchronizacji działania wydziałów KW, ciągłe reorganizacje oraz zbytnią płynność kadrową. W efekcie konstatował, że „efekty pracy AKW niewiele są zależne od dobrego planowania, ale od klimatu, zakresu samodzielności, jakie stworzy się pracownikowi AKW w instancji terenowej" ${ }^{35}$. Domyślamy się, że tego właśnie archiwiście KW PZPR w Białej Podlaskiej brakowało.

Archiwum KW PZPR w Białej Podlaskiej przestało istnieć na skutek samorozwiązania się partii 29 stycznia 1990 roku. Decyzją Rady Ministrów z 19 marca 1990 roku materiały archiwalne PZPR stały się własnością państwa i trafiły do archiwów państwowych ${ }^{36}$. Dokumentacja zgromadzona w AKW w Białej Podlaskiej została przejęta przez Archiwum Państwowe w Lublinie, Oddział w Radzyniu Podlaskim 29 czerwca 1990 roku, za pośrednictwem bialskiej struktury sukcesora PZPR - Socjaldemokracji Rzeczypospolitej Polskiej. Akta przejęto na podstawie bardzo fragmentarycznych, niekiedy nieodpowiadających faktycznemu stanowi, spisów zdawczo-odbiorczych. Nabytki zostały zakwalifikowane jako jeden zbiór, któremu nadano

32 Tamże, sygn. 612, s. 82 - protokół z kontroli KW PZPR w Białej Podlaskiej, przeprowadzonej w dniach 7-10 XI $1988 \mathrm{r}$.

33 Tamże, sygn. 611, s. 60 - ankieta.

34 Tamże.

35 Tamże, s. 64.

36 E. Łaborewicz, dz. cyt., s. 7. 
nazwę: „Archiwum Komitetu Wojewódzkiego PZPR w Białej Podlaskiej”. Składały się nań akta wszystkich instancji partii województwa bialskopodlaskiego (KW, KM, KG, KZ, POP), a także dokumentacja odziedziczona po komitetach powiatowych w Białej Podlaskiej, Łosicach i Radzyniu Podlaskim. Wielkość tego zbioru wyniosła 4768 j.a., 72,90 m.b. ${ }^{37}$ Analiza „Księgi Inwentarzowej" Archiwum KW z lat $1977-1989^{38}$ pozwala na sporządzenie spisu zespołów tworzących jego zasób w momencie likwidacji PZPR. Miałby on postać następującą:

1. KW PZPR w Białej Podlaskiej,

2. Rejonowy Ośrodek Pracy Partyjnej w Radzyniu Podlaskim,

3. KM PZPR w Białej Podlaskiej,

4. KM PZPR w Międzyrzecu Podlaskim,

5. KM PZPR w Parczewie,

6. KM PZPR w Radzyniu Podlaskim,

7. KMG PZPR w Łosicach,

8. KMG PZPR w Parczewie,

9. KMG PZPR w Radzyniu Podlaskim,

10. KMG PZPR w Terespolu,

11. KG PZPR w Białej Podlaskiej,

12. KG PZPR w Ciemiernikach,

13. KG PZPR w Dębowej Kłodzie,

14. KG PZPR w Drelowie,

15. KG PZPR w Hannie,

16. KG PZPR w Huszlewie,

17. KG PZPR w Jabłoniu,

18. KG PZPR w Janowie Podlaskim,

19. KG PZPR w Kąkolewnicy,

20. KG PZPR w Kodniu,

21. KG PZPR w Komarówce Podlaskiej,

22. KG PZPR w Konstantynowie,

23. KG PZPR w Kornicy,

24. KG PZPR w Leśnej Podlaskiej,

25. KG PZPR w Łomazach,

26. KG PZPR w Międzyrzecu Podlaskim,

27. KG PZPR w Milanowie,

28. KG PZPR w Olszance,

29. KG PZPR w Parczewie,

37 D. Magier, Wstęp do inwentarza, s. V.

38 APL, O/R, KW PZPR w BP, sygn. 614. 
30. KG PZPR w Piszczacu,

31. KG PZPR w Platerowie,

32. KG PZPR w Podedwórzu,

33. KG PZPR w Radzyniu Podlaskim,

34. KG PZPR w Rokitnie,

35. KG PZPR w Sarnakach,

36. KG PZPR w Siemieniu,

37. KG PZPR w Sławatyczach,

38. KG PZPR w Sosnówce,

39. KG PZPR w Tucznej,

40. KG PZPR w Ulanie-Majoracie,

41. KG PZPR w Wisznicach,

42. KG PZPR w Wohyniu,

43. KG PZPR w Zalesiu,

44. KZ PZPR przy Bialskich Fabrykach Mebli w Białej Podlaskiej,

45. KZ PZPR przy Komendzie Wojewódzkiej MO w Białej Podlaskiej,

46. KZ PZPR przy Rejonie Przeładunkowym w Małaszewiczach,

47. KZ PZPR przy Wojewódzkim Urzędzie Spraw Wewnętrznych w Białej Podlaskiej,

48. KZ PZPR przy Zakładach Przemysłu Wełnianego „Biawena” w Białej Podlaskiej.

Ze względu na miejsce PZPR w systemie władzy w okresie PRL-u materiały archiwalne wytworzone przez poszczególne instancje partii znacznie odbiegają swoim charakterem, a tym samym i znaczeniem, od dokumentacji powstałej w wyniku działalności partii politycznych w okresie Drugiej czy Trzeciej RP. Nadrzędność PZPR, określona konstytucyjnie jako „przewodnia siła" 39 we wszystkich dziedzinach życia w Polsce w latach 1948-1989, sprawia, że materiały archiwalne wytworzone przez tę partię należy znaczeniowo traktować na równi z aktami organów władzy państwowej. Akta KW PZPR w Białej Podlaskiej zawierają takie informacje w odniesieniu do terenu województwa bialskopodlaskiego z lat 1975-1989. Już dokumentacja samego Komitetu Wojewódzkiego, z uwagi na jego strukturę, przyniesie informacje z zakresu życia społeczno-politycznego, gospodarczego i kulturalnego województwa. Na przykładzie regionu bialskopodlaskiego można prześledzić pro-

39 Konstytucja Polskiej Rzeczypospolitej Ludowej, art. 3, pkt 1, zob. DzU, 1976, nr 7, poz. 36 (tekst jednolity z dnia 16 lutego 1976 r.); w sprawie ówczesnej wykładni kierowniczej roli PZPR w ustroju PRL-u patrz: A. Dobieszewski, A. Lutrzykowski, PZPR wsystemie politycznym PRL, [w:] PZPR (1948-1978), red. A. Dobieszewski, J. W. Gołębiowski, Warszawa 1978, s. 85-135. 
ces realizacji poszczególnych zadań, począwszy od stadium roboczego (praca komisji i zespołów problemowych KW), decyzyjnego (uchwały Konferencji i Plenum), poprzez wdrażanie ich w życie (działalność Egzekutywy i Sekretariatu KW) i realizację (sprawozdania i analiza działalności poszczególnych instancji terenowych). Informacji o strukturze, organizacji i funkcjonowaniu aparatu partyjnego w województwie bialskopodlaskim dostarczają akta Wojewódzkiej Komisji Kontroli Partyjnej, Sekretariatu KW, Kancelarii I Sekretarza, a zwłaszcza Wydziału Polityczno-Organizacyjnego. Znajdą się w nich m.in. informacje dotyczące sytuacji wewnątrzpartyjnej i nastrojów społecznych, które zawierają wiadomości teleksowe wysyłane do KC, np. dla okresu pierwszej „Solidarności (1980-1981) i stanu wojennego ${ }^{40}$. Na dokumentację poszczególnych wydziałów KW składają się plany pracy, protokoły z posiedzeń danego wydziału, komisji problemowych obsługiwanych przez wydział oraz narad przezeń organizowanych, a także informacje ogólne z zakresu działania wydziału.

Osobną grupę akt stanowią teczki osobowe działaczy ruchu robotniczego, wdów i sierot po działaczach, gromadzone przez Referat ds. Działaczy Ruchu Robotniczego. Standardowo zawierają one wnioski o zaliczenie w poczet „działaczy ruchu robotniczego”, formularze obrazujące przebieg działalności politycznej, a dzięki mieszczącym się w niektórych z nich wspomnieniom działaczy mogą stanowić wartościowy materiał do badań nad kształtowaniem się ruchu komunistycznego na południowym Podlasiu w okresie istnienia Komunistycznej Partii Polski i Polskiej Partii Robotniczej.

Spośród akt pozostałych po KW PZPR wydzielono sporą grupę broszurowych wydawnictw własnych $\mathrm{KW}$ oraz podobnego charakteru wydawnictw obcej proweniencji (zwłaszcza KC, ale także urzędów i instytucji nadzorowanych przez KW PZPR), które w kilkunastu, kilkudziesięciu egzemplarzach przygotowywano na konferencje, posiedzenia plenarne, egzekutywy lub po prostu do wiadomości PZPR jako materiał informacyjny. Są to kolejne egzemplarze dokumentów, które znalazły swoje miejsce w załącznikach z posiedzeń poszczególnych organów kolegialnych, oraz oryginały, których miejsce w pierwotnym układzie kancelaryjnym było trudne do określenia. Uzupełniają one informacje o funkcjonowaniu PZPR oraz jej wojewódzkiego szczebla w Białej Podlaskiej, dotyczą różnych dziedzin życia społeczno-gospodarczego, a także rzucają światło na stosunki łączące partię z administracją państwową, gospodarczą, instytucjami, zakładami pracy itp.

40 Zob. D. Magier, Lata 1980-1981 w województwie bialskopodlaskim. Wybór teleksów Komitetu Wojewódzkiego Polskiej Zjednoczonej Partii Robotniczej, Radzyń Podlaski 2006. 
Standardowy (z reguły) jest układ akt komitetów I stopnia, na który składa się dokumentacja z konferencji partyjnych, plenów i egzekutyw, komisji rewizyjnych i komisji kontroli partyjnej.

\section{Archives of Voivodship Committee of Polish United Workers' Party in Biała Podlaska}

Summary

Documentation generated by the communist party after World War II constituted the part of Polish archival heritage. However, Party's archives were not supervised by national archival network. At the beginning they were storehouses of acts, and since 1955 they had been taken over by propaganda sections of voivodship committees of PZPR (Polish United Workers' Party) and later transformed into the archives of voivodship committees of the Party. The task to preserve documentation generated by the structures of the communist party in Poland was subsequently supervised by: Party History Institute at KC PZPR (Central Committee of Polish United Workers' Party), Archives of KC PZPR, and since 1971 Central Archives of KC PZPR. Together with the archives of voivodship committees the net with its own regulations, staff and archival methodology was created.

This article gives a detailed description of the activity of the organizational unit, that is the archives of the voivodship committee of the communist party. One of the smallest committees existing in Poland, a provincial Voivodship Committee of PZPR in Biała Podlaska, which operated from 1975 to 1990, serves as an example. The article discusses the reporting structure, handing-over, analysis and preservation of acts, means of recording, premises, system of training and control as well as characterizes the role of a supervisor of the Party's voidovdship committee Archives played in the archives and chancery. 